\title{
WIELKI TEATR ŚPIEWEM OWIANY
}

\author{
JADWIGA GAEĘSKA-TRITT
}

Świat teatrem, gra wszystko, aktorowie wszędzie; kto nie gra, może patrzeć; ale płacić będzie.

Józef Dyonizy Minasowicz (zapis z kartki kalendarza z 28 października 1973 r.)

Nie ma chyba na naszej Planecie człowieka, który nie chciałby być dobrze postrzegany przez innych ludzi. Nie żyjemy na bezludnej wyspie, a i tam trzeba wiedzieć jak postępować, czym się posługiwać, jak wykorzystywać swoje zdolności i rozum dla dobra własnej egzystencji i otaczającego nas środowiska. Sprawa ta dotyczy wszystkich ludzi niezależnie od czasowych epok, różnorodności przypadków życiowych i historycznych zawieruch. Jednostka ludzka oprócz swojej fizyczności, posiada elementy z tzw. „wyższej półki”, jak: emocja, wola, pragnienia, które stworzone intuicyjnie, są segregowane i utrwalane przez świadomość. Właśnie to świadome poczucie swojego EGO w odniesienu do funkcjonalności całego ciała, tworzy z nas ludzi różnorodnych profesji, współodnoszących się do siebie, współdziałających, kreujących siebie i innych, rozwijających, pomocnych, etc., (bywa, że także ludzi niszczących innych - ale nie o tym będzie ta rozprawka). $Z$ pośród wielu wielu humanistycznych zawodów wyróżnia się jeden - aktorstwo. Jest to niewątpliwie ekstrawertycyzm, którego celem jest oddziaływanie na ludzi, na środowiska, a nawet bywa, że na biegi historyczne. Nasz wielki Polak i współczesny polski święty - papież Jan Paweł II przedstawił krótką, lecz jakże istotną charakterystykę artystów: „W rozległej panoramie kultury każdego narodu artyści mają swoje miejsce. Gdy idąc za głosem natchnienia tworzą dzieła naprawdę wartościowe i piękne, nie tylko wzbogacają dziedzictwo kulturowe każdego narodu i całej ludzkości, ale peł- 
nią także cenną posługę społeczną na rzecz dobra wspólnego” („Elementarz Jana Pawła II", Wydawnictwo Literackie Kraków 2005, s. 13).

Papież w swej wypowiedzi odniósł się do twórców, autorów dzieł artystycznych. Jednak ich mistrzostwo w zakresie utworów teatralnych i muzycznych nie miałoby wartości, bez kunsztu odtwórców - tych, którzy na otwartej scenie współtworzą zapisane graficznie dzieła. Do nich właśnie należą aktorzy dramatyczni, muzycy wszelkiego instrumentarium, a przede wszystkim - śpiewacy.

Jako wokalistka zajmę się właśnie tym nurtem ekspresji człowieka, który angażuje go całościowo jako muzyczny instrument z jego ,psyche i physis”.

\section{Talent a wola}

Rozpocznę ten rozdział cytatem z własnego artykułu: „Od zarania wieków fenomen sztuki wokalnej zachwycał, wychowywał i bawił każdy ze stanów społeczności ludzkich. Śmiało można też zaryzykować stwierdzenie, że śpiewacy byli i są najbardziej podziwianymi i znanymi artystami (najbardziej eksponowanymi medialnie) spośród wszystkich specjalności muzycznych. Piękno brzmienia głosów zespolonych - chórów, wirtuozeria oraz wszechstronna popisowość indywidualnych wokalistów zainspirowały i nadal inspirują najznakomitszych kompozytorów kolejnych stuleci, do tworzenia różnorodnych form utworów wokalnych i wokalno-instrumentalnych” („Twoja Muza”, nr 4/2007, s. 66).

Można i trzeba postawić pytanie: jak dojść do fenomenu szerokiego oddziaływania na innych ludzi, jak zasłużyć na powszechne uwielbienie i wielki podziw dla swojej sztuki wykonawczej? Wśród muzyków krąży na ten temat bardzo stary dowcip: Nie znający miasta przyjezdny pan, pyta napotkanego przechodnia: „panie kochany jak dojść do filharmonii?” i styszy odpowiedź: „panie kochany-ćwiczyć, ćwiczyć, ćwiczyć!!!"”. Podobnie, chociaż nie humorystycznie traktuje muzyków wielki polski artysta - pianista wszechczasów Artur Rubinstein twierdząc, iż do wirtuozerii wykonawczej trzeba $99 \%$ pracy i $1 \%$ talentu. Czy jednak samo ćwiczenie i jego konsekwencja prowadzi do zdobycia „miłości tłumów”? Co decyduje o wielkim powodzeniu osób uwielbianych przez tłumy? Co kazało tymże tłumom nosić na rękach słynnego tenora - Jana Kiepurę? Jaką więc osobowość posiadają „wokalni idole”? W naszym rozważaniu skupimy się na tych wokalistach, którzy zdobyli sławę na wielkich scenach i estradach świata, wykonując dzieła z gatunku opery, operetki, oratorium, kantat - tej sztuki, której nie określa się jako ,popularną”.

Natura niewątpliwie obdarzyła takich artystów pewnego rodzaju talentem. Słowo talent oznaczało w starożytności największą jednostkę monetarną, więc i jego znaczenie współczesne ma swoje odniesienie do najcenniejszych walorów człowieka. Bywa, że mówi się o kimś wybitnym, iż posiada wiele talentów, czyli uzdolnień, predyspozycji, a w języku popularnym używa się też takich określeń jak: smykałka, 
dryg, czy - nerw. Talent wokalny wykazują te osoby, które potrafią swoją jakością głosu, pięknem jego brzmienia i nieskalaną intonacją zachwycić innych ludzi, spowodować ich zadowolenie, wywołać pozytywne reakcje, chęć do uszlachetniania siebie i innych, itp.

Zdolności wokalne posiada wielu. Znowu posłużę się dowcipnym powiedzeniem, że: „śpiewać każdy może, trochę lepiej, trochę gorzej”. Na pewno większość naszego społeczeństwa śpiewa i to właśnie nienajgorzej. Bywają artyści ludowi, osoby mniejszych kręgów różnych społeczności, które wiodą prym w swoich środowiskach właśnie poprzez to, że potrafią zaśpiewać czy poprowadzić wspólne śpiewy. Tacy ludzie są poważani, sami też starają się o swój wizerunek - czyli taki obraz, który nie zamaże pozytywnych wrażeń wywołanych kunsztem ich śpiewu. Steruje nimi bowiem wewnętrzna potrzeba piękna i dobra, a ich osobowości są pełne dobrej woli do dokonywania rzeczy wzniosłych. Synonimami słowa „wola” mogą być: chęć, zapał, skwapliwość, ochota, pragnienie nawet poświęcenie, a w moim odczuciu: - WOLA zawiera wszystkie te określenia. Sa one sktadowa największego, międzyludzkiego obowiązku - ludzkiej WOLI. Jakość tego słowa podkreśla zdanie przysięgi małżonków w kościele, przed ołtarzem i w Obliczu Boga, iż „....mam dobrą i nieprzymuszoną wolę poślubienia...”.

Swoistą cechą śpiewaków jest ich dążenie do pokazania się innym, wyzwolenia śpiewem swoich namiętności, inaczej mówiąc, jest to potrzeba sceny. Osoby obdarzone „popisowym głosem” są ,popychane” niejako tym naturalnym przymusem i już w okresie dzieciństwa chętnie śpiewają, mówią wierszyki, biorą udział w różnego rodzaju scenkach i spektaklach. Akceptacja środowisk - rodziny, szkoły a nawet kolegów z podwórka, utrwala ich wole dziatania w kierunku okazywania swojego talentu. Posiadanie takiej cechy pozwala każdemu człowiekowi być twórczym, kształcącym się, krytycznym wobec siebie i poszukującym w kontekstach swoich wykonywanych funkcji. Odnosi się to przede wszystkim do przekazów artystycznych, w których powinna występować w osobowości wykonawcy całkowita integralność talentu i woli. Takie właśnie zespolenie musi w sobie posiadać wokalista. Gra on bowiem całym swoim ciałem. Gra sprawność jego muskulatury, gra rezonacyjność kości, szczególnie głowy, gra wyobraźnia intonacyjno-barwowa, a steruje tą grą centrum jego „psyche” - mózg, który jest jednocześnie i dowódcą wydającym ciału rozkazy psychofizyczne i kontrolerem oceniającym wykonanie tych rozkazów w efektach akustycznych. Wykonawczy krąg wokalisty to:

- wyobrażenie dźwięku - jego wysokości, dynamiki, barwowości w centrali (mózg - psyche);

- rozkaz czynnościowy do muskulatury odpowiedzialnych narządów poprzez drogi czuciowe (mózg - psyche);

- czynności mięśniowe poprzez receptory nerwowe i czuciowe, czyli świadoma, systematyczna i energetyczna funkcja muskulatury (physis); 
- rozchodzenie fal głosowych $\mathrm{w}$ środowisku - poza ciałem-instrumentem (akustyka);

- odbiór fal przez - membranę słuchową i kosteczki ucha środkowego - analizator słuchowy (physis);

- informacja o przebiegu całości procesu nerwowego i akustycznegoi i kontrola w centrali - (mózg - psyche).

Krótko mówiąc - jednocześnie przebiega proces nadawczy fali głosowej i jego kontrola akustyczno-fizjologiczna. Czynności te są odczuwalne przez człowieka jako jedność czasowa pod warunkiem, że jego mózg działa przez receptory energetyczno sprawnej muskulatury. Taki fenomen psycho-fizjo-akustyczny może tylko zaistnieć w instrumencie głosu, którym jest cały człowiek - z jego „psyche” i „physis”. Inne instrumenty - chociaż posiadają wiele walorów przewyższających głos ludzki jak skala, potęga brzmienia, możliwości gry w wielogłosie, są jednak zależne od głównego i pierwszego instrumentu - osobowości instrumentalisty, który na nich gra. Gtos ludzki - to cały cztowiek, to instrument najwspanialszy i najważniejszy we wszystkich sferach światowej, międzyludzkiej kultury.

\section{Ciało a dusza}

Przyjmując, iż całe ciało człowieka jest instrumentem komunikacji międzyludzkiej, musimy uznać, że nie wolno nam rozpatrywać jego funkcjonalności wyłącznie jako samopodtrzymujący się system energetyczny, który współreaguje ze środowiskiem i którego przetrwanie zależy od środowiska. Wspomniane powyżej „physis” nieodłącznie współdziała z „psyche” - duchowością, czyli zdolnością odczuwania, przeczuwania, przewidywania, spontanicznością, namiętnością, także łącznością ze światem mistycznym, definiującym się jako wpływ i poczucie łączności z siłą potężniejszą, niż my sami.

Duch i materia są nierozdzielne dla życia i trudno jest ustalić pryncypia, które z nich należy przedkładać jako pierwsze w działaniu artystycznym. Ta problematyka przewija się poprzez ludzkie dzieje, od starożytności, po dzień dzisiejszy. Stanowi także podstawy doktryny z epoki baroku o podporządkowaniu afektów, czyli stanów ducha, muzyce - szczególnie w jej religijnym wymiarze. Siedemnastowieczny filozof i teoretyk muzyki Athanasius Kircher wymienia osiem afektów, które można wyrazić w muzyce, a są to: miłość, smutek i żal, radość i uniesienie, złość i oburzenie, wzruszenie i płacz, strach i przerażenie, gwałt i zuchwalstwo oraz podziw (za Paczkowski Szymon, „Nauka o afektach w myśli muzycznej I połowy VII w.”, Polihymnia, Lublin 1998, s. 117).

Tym afektom przypisuje się także różne stany ducha, objawiające się w intonacji głosu śpiewaka, jego dynamicznym natężeniu, zmianach agogicznych (tempa) i różnorodności rytmicznej, bezpośrednio wynikających z gestów i emocjonalnego 
zachowania się całego ciała. Śpiewak wyraża różne namiętności sterując swoim instrumentem głosu, stwarza obrazy porzez słowa i muzyczne frazy, które nakreślił kompozytor. Stara się, by słuchacze odebrali wszystkie jego zachowania emocjonalne, jako autentyczne przeżycia, by jednocześnie podziwiali kunszt wokalny, stylowość wykonawczą, a także ubiór, elementy stroju, grację poruszania się, piękno postaci, makijaż, itp.

Nie będzie artystą ten, kto „wyrzuca z siebie” uczucia w sposób nieopanowany z nadmierną ekscytacją lub zbytnio dba o techniczną stronę ,,wokalu”, co zazwyczaj hamuje - blokuje mięśnie i naturę emocjonalnych gestów. Zarówno w pierwszym, jak i w drugim przypadku zachowania takie nie sprzyjają właściwemu artyzmowi. W środowiskach muzycznych krąży wiele żartów na temat wokalistów: Mówi się, że „są wśród nich śpiewacy i bywają głosy”, i z tych bardziej dokuczliwych (szczególnie ze środowiska muzyków - instrumentalistów): „Pytanie - po czym poznać, że chce ci złożyć wizytę śpiewaczka? Odpowiedź - po tym, że puka nierówno i wchodzi za późno!”. Żarty te nie narodziły się z niczego. Otóż zsynchronizowanie funkcjonalnego ciała $\mathrm{z}$ duchowością emocjonalną to trudne zadanie, problem i dyscyplina całego życia śpiewającego muzyka.

Ciało, czyli instrument fizyczny, musi być utrzymywany w sportowym stylu bycia, dyscyplinie zachowań i higienie, które decydują o jego zdrowiu. Upragniona przez śpiewaka scena ma swoje wymagania. Minęły bowiem czasy gdy „Gruba dama śpiewała”. Obecnie „divy” operowe są smukłe i wygimnastykowane. Czarują wdziękiem ruchów i modulacjami głosów. Od śpiewaków wymaga się też wykonywstwa w różnorodnych stylach. Nauka stwierdza bowiem, że: ,...nie ma w ludzkim mózgu jednego centrum muzycznego, lecz w związku z muzyką uruchamianych jest kilkanaście sieci rozproszonych po całym mózgu" (Sacks Oliver, Muzykofilia. Opowieści o muzyce i mózgu. Wyd. Zysk i S-ka, Poznań 2009, s. 12). W świetle powyższego, nie jest niczym zadziwiającym, że wokaliści sięgają po różnorodne kompozycje. Ta cecha mózgu ludzkiego stanowi też o inności jakościowej wokalistów, nawet wtedy, gdy śpiewają te same utwory, partie operowe, itp. To ich odróżnia i decyduje o wtasnym stylu i charakterze wykonawczym.

W poprzednim rozdziale przedstawiłam drogę nerwowo-fizyczno-akustyczną dźwięku wypływającego falą z ludzkiego instrumentu. Tenże instrument podatny jest na różnorodne słabości, choroby, na trudności życiowe. Podczas gdy fortepian, czy ograny możemy stroić co pewien czas, instrument głosu musi być w swej fizyczno-psychicznej i słuchowo-akustycznej formie „strojony” codziennie, utrzymywany w higienie, zdolności i gotowości do gry.

Dużo by pisać o sprawnościach ciągle ćwiczonych jak: technika filacji rezonacyjnej, technika otwarcia gardła (najtrudniejsza, gdyż najbardziej reagująca na stany psychiczne człowieka), technika przestrzenności klatki piersiowej, dzięki której wyzwala się energia a u śpiewaka - energia kontrolowana kanonami frazowymi, technika ciśnień i krążeń emocjonalnych - ściśle sterująca przebiegami odczuć od- 
dechowych, który to oddech nabiera w krtani cech dźwięku i formowany w jamie gardłowo-ustnej, zachwyca publiczność. Oparciem dla wszystkich wymienionych technik sa sprawne, rytmiczne, silne, elastyczne nogi z ich mocnq podstawa stopami.

Taki to jest wymóg dla wokalisty, by jego emocjonalność nie „wyciekła” poza sprawność ciała. Nieradzenie sobie z przesadnymi emocjami sprawi, że śpiewak będzie „ciężkostrawny”, niewiarygodny, że bardzo ucierpią przedstawione przez niego afektacje - duchowość, a tym samym i interpretacja. Nie mówiąc już o tym, iż takie niezgranie ciała i duszy wpływa na jakość muzyczną, jak: potknięcia w intonacji, niedokładność rytmiczna, zaburzenia w tempach i chimeryczność dynamiczna.

$\mathrm{W}$ podsumowaniu funkcji wokalnych - wyłania się jednak na prowadzenie, jego intelekt na równi z duchowością, które bliższe są człowieczeństwu, niż samo ciało. Ciałem człowieka, a do tego - artysty sterują (a czasem nawet rządzą) namiętności i emocje. Musi on więc wykorzystywać tę naturę pulsacji organicznych, które współgrają z rytmotempem kolejnych, śpiewanych fraz. Jednym słowem - śpiewak musi posiadać inteligencję, wiedzę, sprawność całego ciała, bystrość umysłu i niebywały refleks obserwacjno-sytuacyjny. Śpiew bowiem, to intelekt, dusza i ciało w całkowitej automatyzacji swoich funkcji.

\section{Artyzm a wizerunek}

Zaznaczyłam już w niniejszej pracy, że śpiewacy to bardzo uprzwilejowana i pożądana przez publiczność „kasta” artystyczna. Nie odbiega ona w swoim historycznym prawzorze od przedstawicieli innych sztuk zarówno muzycznych, jak i pozamuzycznych. Człowiek od zarania czasów kształtował w sobie pewne wizje i wizerunki. W tym zakresie nie nastąpiła żadna ewolucja.

Zastanawiając się głęboko nad życiem współczesnym dochodzimy do wniosku, że pradawne czasy ciągle rządzą i sterują wieloma dziedzinami naszego życia, szczególnie w sferach obyczajowych i artystycznych. Bardzo trafnie sytuacje te określił Zbigniew Herbert w opisie płaskorzeźb portalu katedry w Arles: „Pośród scen ze Starego i Nowego Testamentu odkrywamy nie bez zdziwienia Herkulesa. Cóż robi bohater grecki na romańskim portalu? Zabija nemejskiego lwa. Tylko że nie jest to wcale zabłąkana karta mitologii. Średniowiecze nie znało sztywnego podziału na epoki. Historia rodzaju ludzkiego była tkaniną zwartą jak gobelin. W wyobrażeniach i legendach bohaterowie odległych wieków powracali na ziemię, by wprząc się w nowe prace w służbie nowej wiary. Niezmordowany Herakles zmaga się z grzechem pod postacią nemejskiego lwa".

Z powyższego cytatu wybieram zdanie, które najbardziej wpisuje się w kontekst niniejszego artykułu a mianowicie: „Historia rodzaju ludzkiego była tkaniną zwartą jak gobelin”, z tym uaktualnieniem, że historia rodzaju ludzkiego jest ciągle w wielu 
dziedzinach społeczno-życiowych tą zwarta jak gobelin tkanina. Dotyczy to przede wszystkim ludzkich emocjonalności (Herbert Zbigniew, „Barbarzyńca w ogrodzie”, Fundacja Zeszytów Literackich, Warszawa 2004, s. 46).

Każdy artysta sceny opracowuje siebie jako postać, którą przedstawia, zdobywa techniki dramaturgiczne, ćwiczy wyobraźnię, pamięć i tempo reakcji. Ma w swej podświadomości genetyczne bohaterstwo (lub nie ma), łatwość wysławiania się (lub pewne defekty aparatu artykulacyjnego), elastyczną muskulaturę ciała (lub jest aruchowcem), lecz jego wola pokazania talentu wokalnego popycha go do pracy nad swoimi większymi lub mniejszymi zdolnościami - do pracy nad swoim wizerunkiem.

Starałam się w poprzednich rozdziałach przedstawić złożoność psycho-fizyczno-akustyczną osobowości wokalisty. Tworzenie jego wizerunku jest o tyle trudniejsze, iż kształcenie śpiewaków zaczyna się w ich wieku późniejszym - tzw. późnomłodzieżowym, w którym to okresie mogą zaistnieć już pewne ograniczenia osobowościowe, wynikające ze stosunków szkolnych, rodzinnych, społecznościowych itp. Instrumentalista, np.: pianista czy skrzypek, zaczyna przygodę z muzyką w bardzo wczesnym okresie życia (nawet od 3-4-ech lat), co kierunkuje jego życie i przez to niejednokrotnie unika on różnych skrępowań, które odczuwa osobnik kilkanaście razy od niego starszy, zaczynający naukę śpiewu. Wielka więc rola pedagoga, który otrzymując w darze od losu młody talent wokalny, musi spojrzeć na niego całościowo, jako na instrument do psychofizjologicznego uruchomienia go. To pedagog podsuwa pierwsze odczucia i wizje młodemu adeptowi, bada jego predyspozycje, słabe miejsca i dobre w swej naturze, w podświadomości. Powinien odważnie dyskutować z uczniami (studentami) o ich odczuciach, uczuciach, nie bać się trudnych tematów, nawet tych, dotykających orientacji seksualnej, czy spraw rodzinnych, światopoglądowych etc.

Oczywiście - taki pedagog musi być bardzo głęboko wykształconym człowiekiem, znać kanony psychologii i posiadać najwyższe kwalifikacje pedagogiczne, nie wspominając już o sferze moralnej. Uczeń powinien mieć do niego zaufanie, móc liczyć na jego dyskrecję, zrozumienie i pomoc. Wypracowując jakość wokalną trzeba jednocześnie tak kierunkować śpiewaka, by nie zagubiła się „ludzka” strona jego osobowości, by zachwycając się tylko swoim brzmieniem, nie zapomniał o duchowości, by nie załamały się inne elementy jego woli śpiewania.

W wyniku zakłóceń tychże jedności - talentu, woli, duchowości itp., może wystąpić u wokalisty niekorzystna cecha, zwana narcyzmem. Artysta narcystyczny jest przeważnie taką osobą, która zbyt wcześnie uwierzyła w swoją naturę talentu. Zdarza się to wskutek zbyt szybkiego poklasku środowiska, pewnych niekoniecznie artystycznych układów, niedostatecznej woli pracy nad sobą itp.

Uczony - psycholog z Nowego Jorku Alexander Lowen tak przedstawia tę niezbyt pochlebną ludzką cechę: „Narcyzm jest najczęstszym utrapieniem współczesnego człowieka. Jednostka narcystyczna żyje, kryjąc się za fasadą mającą na celu $\mathrm{z}$ jednej strony zdobycie akceptacji i podziwu, a z drugiej kompensację i zanegowa- 
nie wewnętrznych uczuć niższości, niedorastania do wymagań, smutku i rozpaczy" (Lowen Alexander, „Duchowość ciała”, Jacek Santorski \& Co Agencja Wydawnicza Sp. z o.o., Warszawa, Wydanie II 2006, s. 229).

W świetle powyższego cytatu bardzo dziwnym się wydaje, że zdarzają się ,idole", nie tylko w zakresie śpiewów rozrywkowych, ale i tych - klasycznych, którzy nie będąc wybitnymi artystami, potrafią przynajmniej przez jakiś okres błyszczeć na scenach światowych. W opisanych wypadkach, jak i w wielu innych znanych nam z życia, drogę wątpliwego artysty wyznacza tzw. „mamona” i - wspomniane już uprzednio, szczęśliwe dla niego życiowe układy. Są więc i takie przykłady artyzmu $\mathrm{z}$ niską poprzeczką. To $\mathrm{w}$ tych właśnie środowiskach tzw. „artyści” wspomagają swój wizerunek dodatkowymi ,gadżetami”.

Wprowadzanie i stosowanie udziwnień swojej wizualizacji poprzez kolczyki w nosie i w innych częściach ciała, wykłuwanie drastycznych tatuaży, noszenie „agresywnej biżuterii” i różne, inne udziwnienia sprowadzają pojęcie artyzmu na niziny jego egzystencji. Bywały wprawdzie takie osobowości artystyczne jak Elwis Presley czy Freddi Mercury, którzy „wydziwiali” w swoich strojach, lecz byli to także wykształceni muzycy i wspaniali wokaliści. Natomiast beztalencia, które bezpodstawnie stylizują się na jakichś idoli, naśladują ich styl ubierania, czesania, „łkają" nieudolnie naśladując ich głosy - to żałośni nieudacznicy, bezosobowościowcy! Nie tworzą oni żadnej wizyjności - to wizerunkowe zera!

Przypomina mi się niegdyś przeczytane zdanie, które wypowiedziała w pewnym czasopiśmie włoskim Maria Callas. Wyznała ona, że za każdym razem, gdy przystępuje do przygotowania nowej partii operowej, najpierw uczy się jej poprzez poznanie historii tej opery, jej kraju, dawnych i obecnych zwyczajów, następnie pracuje nad sobą jako aktorka dramatyczna i dopiero w tak uświadomione i ukształtowane warunki swojej osobowości wprowadza muzykę i śpiewanie. Pani Maria Callas najpierw wypracowywała w sobie obraz danej postaci, a potem wizerunek ten przedstawiała (identyfikując się z nim) wielbicielom jej wokalno-aktorskiego talentu.

Śpiewacy klasyczni, szczególnie ci operowi, operetkowi i musicalowi, nie tylko muszą władać szerokim wachlarzem technicznym śpiewu, ale i aktorskim, dramaturgicznym. W ich wizerunku jest cały zestaw najwyższej, światowej kultury i twórczości znakomitych kompozytorów. Tworząc postaci z epok, z historii i obyczajów, z toczących się wojen, z legend lub postaci ze świata komedii i lekkiej muzy, muszą przedtem głęboko studiować odpowiednią literaturę, znać kilka języków, by móc przekonać wyrafinowaną publiczność o autentyzmie swojej sztuki, przenieść ich wizerunkowo w żywe pejzaże malowane słowem i muzyką. Sztuka wokalna musi być integracja zachowań $w$ szerokim pojęciu dramaturgii ciała - co stanowi o obrazie catościowym artysty - o jego wizerunku, który akceptuje odbiorca, zachwyca się nim i ciagle oczekuje od niego dalszych, wysoce kulturowych przeżyć.

$\mathrm{Na}$ koniec czuję się w obowiązku wspomnieć o tandetnym wychowaniu muzycznym dzieci i młodzieży naszych czasów. Panuje wszakże wielkie ożywienie 
w kierunku śpiewania. Są ,trenerzy śpiewu” (okropna nazwa) tresujący młodych w kierunku krzykliwego wyzwalania energii w śpiewie, tworząc z nich stworzenia wizerunkowo bezosobowe, śpiewające na tzw. „podkładach akompaniujących”, które nie pozwalają na swobodne wyśpiewanie się młodego człowieka. Nie może bowiem żaden człowiek śpiewać pod szablony rytmiczne i emocjonalne, narzucone przez przypadkowych muzyków, czy innych wokalistów. Takie kształcenie zniewala śpiewaka, nie wyzwala jego wizerunkowej osobowości. Nie będzie tworzyło w nim obrazów artystycznych, które muszą grać w wokaliście, obejmując wizerunkowo całość jego psychofizjologicznej osobowości. No cóż! Nastała raczej era szablonów w muzyce popularno-rozrywkowej. Oby ominęła KLASYKĘ!

Kształtowanie, kształcenie i opanowywanie dla sztuki śpiewu własnego ciała jako instrumentu głosu jest wielkim trudem. Jednak wysiłek ten daje ogromną satysfakcję i radość z tworzenia ulotnej wprawdzie, ale właśnie dlatego tak niezwykłej sztuki - sztuki muzykowania głosem i przez to najwspanialszego kontaktu człowieka z drugim człowiekiem. Kontaktu kompromisów, porozumienia i potrzeby wzniosłych przeżyć poprzez światowe wyżyny kulturowe.

\section{Bibliografia}

Andersen, A. 2010. Mowa ciała. Poznań: Dom Wydawniczy Rebis.

Barber, D.W. 2001. Kiedy gruba dama śpiewa. Warszawa: Wydawnictwo Adamantan.

Bristiger, M. 1986. Związki muzyki ze słowem. Z zagadnień analizy muzycznej. Kraków: Polskie Wydawnictwo Muzyczne.

Dehnel, P. 2006. Dekonstrukcja-rozumienie-interpretacja. Kraków: Universitas.

Gałęska-Tritt, J. 2006. Ciało człowieka - pierwszym i najdoskonalszym instrumentem muzycznym z. V. Barczewo: Wydawnictwo Międzynarodowego Festiwalu Muzyki Chóralnej.

Gałęska-Tritt, J. 2007. „Śpiewacy ciała i duszy”. Twoja Muza 4.23. 66-68.

Gałęska-Tritt, J. 2009. Śpiewam solo i w zespole: psychofizjologia śpiewu dla każdego. Poznań: Akademia Muzyczna im. I.J. Paderewskiego w Poznaniu.

Gałęska-Tritt, J. 2010. „In te, anima mea, tempora meteor”. De musica commentarii II. Poznań: Akademia Muzyczna im. I.J. Paderewskiego w Poznaniu. 253-262.

Hannaford, C. 1998. Zmyślne ruchy które doskonala umyst. Warszawa: Medyk.

Herbert, Z. 2004. Barbarzyńca w ogrodzie. Warszawa: Zeszyty Literackie.

Kordys, J. 2006. Kategorie antropologiczne i tożsamość narracyjna. Kraków: Universitas.

Le Doux, J. 2000. Mózg emocjonalny. Poznań: Media Rodzina.

Moir, A. i D. Jessel. 1999. Pteć mózgu. Warszawa: PIW.

Murphy, J. 2000. Potęga podświadomości. Warszawa: Świat Książki.

Paczkowski, Sz. 1998. Nauka o afektach w myśli muzycznej I połowy XVII wieku. Lublin: Polihymnia.

Powell, M. 2011. Jak zostać aktorem. Warszawa: Wydawnictwo Arkady.

Sobierajska-Friedrich, H. 1970. Aktywność muskulatury aparatu głosowego w śpiewie. Poznań: Katedra Problematyki Wych. Muz. PWSM.

Wojciechowska, Z. 2002. Michat Sobeski poglądy estetyczne. Poznań: Akademia Muzyczna im. I.J. Paderewskiego w Poznaniu.

Załazińska, A. 2006. Niewerbalna struktura dialogu. Kraków: Universitas. 